\title{
Two Paradigms - Two Art Worlds: On Constructing the Difference as a Strategy for Validating the Concept of the Artist and Art
}

\author{
Agata Sulikowska-Dejena \\ University of Rzeszów, Poland
}

DOI: https://doi.org/10.18778/1733-8069.17.3.06

Keywords:

modern paradigm,

contemporary

paradigm,

constructing the

difference, art world,

visual arts

\begin{abstract}
The subject of the article is two art worlds in the field of visual arts which currently exist side by side in Poland. These worlds operate as part of two different paradigms of art, which is why two different definitions of the art and artist apply to them, and, in consequence, also different models of operation. What is important in the case of both communities is the process of constructing the difference and separating out their own communities of meanings, being a strategy to lend credence to their own concept of the art and artist, as well as their position in the art world. The aim of the article is to describe the process of constructing internal boundaries in the Polish art world and its division into two separate worlds, what means have been used in that process, as well as what are the consequences of belonging to the two separate art worlds for their participants.
\end{abstract}

Agata Sulikowska-Dejena holds M.A. in Art History (a graduate of Adam Mickiewicz University in Poznań); currently a PhD student at the University of Rzeszów (Institute of Sociological Studies). Her scientific interests include the sociology of culture and the sociology of art, contemporary art, anthropology, and qualitative methodology. She is an art curator and an author of papers on contemporary art, identity, and female artists.

\section{Contact details:}

Instytut Nauk Socjologicznych, Uniwersytet Rzeszowski al. Rejtana 16c, 35-959 Rzeszów

email address: agata.s.dejena@gmail.com

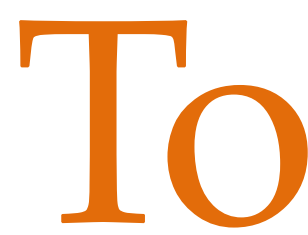

an average observer, the art world described by Howard Becker as "the network of people whose cooperative activity, organised via their joint knowledge of conventional means of doing things, produce(s) the kind of art works that art world is noted for" seems to be quite uniform. $\mathrm{He} / \mathrm{She}$ will easily separate out in the public space specific institutions and actors which make up the contemporary art world, which, in turn, will appear to him/her to be simply another manifestation of the centuries-old tradition. However, what that observer will see will merely be, to quote Anthony 
Cohen, "the common mask," i.e. "the public face" of the contemporary art world, which pretends to be uniform but masks "the private face," which is full of diversity and full of visible boundaries between individual communities (2001:73-74). Artists also "mask the differentiation within itself by using or imposing a common set of symbols," which is why it is important to "discriminate between the common mask and the complex variations which it conceals" rather than describe and analyze this public medium (Cohen 2001:73).

In this article, I focus on artists who create in the area of visual arts as well as on the process of constructing difference, which is an internal boundary between the artistic communities which construct it. The difference results from two different art paradigms - i.e. the modern paradigm and the contemporary one - which exist side by side in the Polish art world and define art and the artist so differently that they, in fact, divide that art world into two separate and incompatible art worlds.

The first paradigm - the modern one - is predominant in the concept of art taught at prestigious universities and practiced by a significant part of professors of fine arts in art schools; it is also common in exhibition programs of the BWA galleries (Artistic Exhibitions Bureaux), which operate in the capitals of the former voivodeships, as well as among the artists associated in the ZPAP (the Association of Polish Artists and Designers) and among continuators of the tradition of plein-air workshops and artistic symposia. I would refer to that model of art and the artistic community connected with it as "the peripheral modernity." The peripherality does not refer to the geographical location of the individual centers but, rather, to their marginal significance; continuing the modern paradigm, but without avant-garde ambitions, these artists hold a secondary position with respect to the mainstream art in Poland and in the world.

The second model, i.e. the contemporary paradigm, is something that I would call "the mainstream contemporariness." The paradigm has originated as a result of criticism of modernity, which is said to be too academic and devoid of avant-garde ambitions. It involves artists connected with the socalled mainstream, i.e. represented by such institutions as centers for contemporary art, avant-garde galleries, and foundations. In the article, the concept of the mainstream will be understood as related to the main, dominant discourse and its circulation in contemporary art worldwide.

The aim of the article is to demonstrate the process in which the artist and art are constructed, and, owing to it, the internal boundaries in the Polish art world as well as divisions within it. It is important to present the means used in that process as well as the consequences - for the participants - of belonging to the separate art worlds. What will be crucial to achieve this purpose is to determine which actors and in what capacity participate in the processes which are important to the art world, as well as who has been authorized to construct valid definitions of the artist and art, what values are involved in the construction processes, what actions and interactions are then initiated by the actors, and what meanings they assign to those actions and interactions.

\section{Research material and methodology}

When writing about the "peripheral modernity" in this article, I use the results of the empirical research conducted in the years 2017-2019 among the visual 
art artists living and working in the Podkarpackie Voivodeship. It was qualitative research: I conducted over 60 one-to-one in-depth interviews with artists as well as over 100 hours of participant observation at art institutions in the region. Furthermore, I conducted a qualitative analysis of the contents of the publications accompanying exhibitions as well as of radio programs (in the form of an interview in the artist's studio) prepared by the regional branch of the Polish Radio. ${ }^{1}$

What I adopted as the main analytical strategy in my research was the grounded theory methodology (Konecki 2000; Charmaz 2006; Glaser and Strauss 2009). The choice of the grounded theory resulted from two factors. First, the research concerned the process and personal experience of the actors participating in it, and the above-mentioned theory focuses on the importance of the analysis of actions and processes. The constructivist grounded theory put forward by Kathy Charmaz makes one sensitive to the multi-faceted nature of constructivist practices. Second, the decision resulted from the need to limit the projection of my own professional knowledge and experience on the direction of the research and the subsequent analysis of data. For over ten years, I worked as a curator of exhibitions, a theoretician, and an art critic, as well as I cooperated with artists based both in the Podkarpackie Voivodeship and in places considered to be centers of contemporary art. It allowed me to gather knowledge of the unique character of the individual milieus, but also involved the risk of formulating conclusions based on intuition rather than data.

\footnotetext{
${ }^{1}$ The radio programs were attached in the form of a CD to three volumes of the Sztuka Podkarpacia album; volume 1, volume 2/2011, volume 3/2013 (ed. Magdalena Rabizo-Birek, Rzeszów: Podkarpackie Towarzystwo Zachęty Sztuk Pięknych).
}

In the case of the second art world - the "mainstream contemporariness" - I used the collective case study method (Stake 1994). In the article, I present the study of three cases, namely three institutions connected with contemporary art: the Ujazdowski Castle Centre for Contemporary Art (UC CCA), the Raster Gallery, and the Foksal Gallery Foundation (FGF). At the time when they began their activity, each of them was something completely new and unprecedented in Poland. Additionally, their activities dominated the public debate on art and art institutions in the short term. I did not include other significant but less influential institutions in this group, such as the Zachęta - National Gallery of Art, because the status of a national gallery meant that it was also obliged to present conservative art. Choosing between the Wyspa Gallery in Gdańsk and the UC CCA in Warsaw, I was guided by the criterion of the extent of influence on the artistic life in Poland in a given period. Thus, the lack of institutions such as the CCA Łaźnia in Gdańsk (inauguration in 1998), the Museum of Modern Art in Warsaw (inauguration in 2008), the MOCAK in Kraków (inauguration in 2010) is due to the fact that they were founded when certain changes had already taken place. In my opinion, the three selected institutions illustrate all the changes and their chronology in the best possible way.

As part of the research, I analyzed the content of the available materials: the texts which accompanied the exhibitions and the critical texts published in Obieg (the magazine about art published by the UC CCA), the collection of texts titled Raster. Macie swoich krytyków. Antologia tekstów, edited by Jakub Banasiak (2009), and the texts published on the websites of the institutions covered by the research. During the analysis, I used the categories developed earlier, and focused on the definitions of the artist 
and art, the social actions taken by the actors, and the values recognized by them.

In the article, an imbalance regarding the depth of the exploration of both art worlds can be perceptible. In the case of "the mainstream contemporariness," I present the results of the first stage of the research (I am planning to conduct one-to-one in-depth interviews with artists at the next stage), which is why they are preliminary, but in my opinion sufficient to outline the specificity of this art world.

Moreover, I analyze the initial periods of these institutions' functioning, as they have changed over the past two decades (i.e. the UC CCA has lost its leading position to the Museum of Modern Art in Warsaw, and the anti-system Raster Gallery has turned into a commercial gallery).

\section{Two art paradigms}

Nathalie Heinich $(2014 ; 2019)$ distinguishes between three leading paradigms in the history of the Western visual art: the paradigms of classical, modern, and contemporary art.

The paradigm of classical art strictly adhered to the academic rules of depiction shaped for several centuries, and it concerned the principle of correct composition, perspective, and use of colors. Modern art (modernism) - associated with the emergence of such movements as impressionism, expressionism, cubism, abstraction, etc. - broke with these rules, and it made expression of the artist's inner life the art's main task, but the changes in the rules of depicting were only formal (Heinich 2019:34-35). Piotr Piotrowski (1999:266) defines modernism as "an international style based on the autonomy of the artistic subject and dominance of esthetics." According to the author, the main strategy of modernism was to neutralize the framework (context) and to melt the art work into "the uniformist world of the common artistic idiom" (Piotrowski 1999:266), which, in consequence, led to the situation in which modernism demonstrated features of formalism and supported the "utopia of the universal language." Piotrowski believes that such a style was always convenient for any type of authority, because it was a style which "avoided critical references to the reality, and was, in fact, decoration which could be defended against trivialization only by discourses of esthetics. History, which was sometimes incorporated in it, tended to be quickly disarmed, and the modernist art work triumphed with the apparent power of its autonomy" (Piotrowski 1999:266).

What is useful in understanding the paradigm of modern art is the concept put forward by Niklas Luhmann (2016), who perceived art as a social system. According to this notion, art is a closed system in terms of its operation, and it produces for itself all operations it needs for its own continuation. In this approach, the history of art is "the conversation of some art works with others," and "does not contain anything imported from outside"; the autonomy of the art system consists in the fact that "the artist is well-oriented in the world of works created earlier and his/her own creative programs" (Piotrowski 1999:278). The differentiation takes place in the context of works which are already recognized and theories which already function; what is more, it requires a limitation of the social factors which apply to the way in which works are created and received, as the art work must be able to differentiate itself from something else; "it must be able to identify that it is about art" (Piotrowski 1999:276); the reduction of contacts with the sur- 
rounding environment is aimed at protecting the boundaries of one's own definition of art.

Heinich also describes two significant changes which took place in the history of art. The first one was the transition from the classical paradigm to the modern one, and the second change was the appearance of the contemporary paradigm, which replaced the modern one as the main trend. The process of the change began in the 1950s and the early 1960s, when pop-art, New Realism and Viennese Actionism emerged (Heinich 2014:35). The precursor and originator of those changes in art was Marcel Duchamp, who was interested in ideas rather than in visual products. In 1917, he created his most significant ready-made work (Fountain), considered by art historians to be iconoclastic in an innovative way and to have the biggest influence on the development of art in the 20th and the 21st century. Duchamp's gesture initiated the conceptual movement, which became crucial for contemporary art at a later stage, but, as Grzegorz Dziamski indicates, what gained advantage as early as in the 1920s was the modernist concept of art, which was embodied in abstraction, whereas the critical avant-garde was pushed off to the margin, outside the main developmental trend of the 20th-century art (2010:10). Various formulas of modernity developed as part of modernism, but what has been the leading formula up till now is different varieties of abstraction, such as geometric abstraction, organic abstraction, structural abstraction, or gestural painting.

In the contemporary paradigm, in turn, the only function of the boundaries is for them to be crossed, as the art is annexing more and more areas, such as politics, religion, or social problems. Artists take intermediary actions, create in alternative spaces outside the framework of traditional institutions, put emphasis on the process-oriented nature of projects, sometimes resign from a material art work, and are satisfied with their role in leading to a given situation or experience. The very structure of the art world and popular practices constitutes a medium in their hands, at the same time changing the rules of participation of the viewer, who not only establishes the meaning of art works and actions, but also influences their final form and course.

\section{Peripheral modernity}

What is characteristic of the artistic community which believes that the modern paradigm is still binding and inspiring is its striving to make the art work and artist as autonomous as possible. Its members believe that the art work is the creation of isolated individuals. Furthermore, in their opinion, only artists are experts in the field of art, so it is them themselves who perform most of the tasks connected with the functioning of the art world. In addition, the fact that they are employed by art institutions and schools helps to sustain the myth of the disinterestedness of art, which is created and exhibited during leisure time, and that its optional sale is not the main source of income.

In the Podkarpackie Voivodeship, most galleries and exhibition rooms are managed by artists who hold the position of institutions' directors or specialists in a given exhibition program. In such a case, those artists also play the role of curators of their colleagues' exhibitions, but the way in which the curator's task is understood here is different than in mainstream institutions. Usually, the author himself/herself chooses the works, arranges the exhibition on the gallery's premises, whereas the curator is merely the author of the text to the catalog which had been agreed with the artist, as well as 
he/she officially opens the exhibition. The inclusion of another person, i.e. a curator, seemingly makes the operation of peripheral galleries similar to the mainstream ones. However, the attitude toward curators is definitely negative; their actions are associated with manipulation and distortion of art:

Well, now it's the curator will tell you what art is. $\mathrm{Cu}-$ rator's position is a bit similar to law. Unfortunately, often it isn't important if somebody is guilty or innocent, but if we can prove it. I'm sorry that I'm saying so, but it sounds as if it was cynical and nonsense. But here this is the case. (22W54)

It is the same with the willingness to make money on art:

I know that the curator is a nice institution, but he/she wants to earn. (51M51)

Curators are perceived as a threat to the existing order and to artists who are in charge of art institutions:

Once I've heard an opinion that "if you want to have curators, why would anybody need you?" (51M51)

Artists who are authorized to construct valid definitions of the art and artist are those, who are recognized by its participants and have the status of the "master," which, in practice, means professors of academies of fine arts as well as artists who have achieved formal mastery confirmed by awards in international competitions. Curators and art theorists do not play a major role either in the process of creating the definitions or in new strategies of institutions' activities, as is the case with critics, who tend to be popularizers of artistic events rather than an important voice in the discussion.
What constitutes the point of reference in the Podkarpackie Voivodeship for all actions and processes is not avant-garde institutions, but the milieu of professors of academies of fine arts who are in charge of traditional art studios and galleries which present traditional art. In a broader perspective, which can be concluded from the examples provided in the statements, what inspires is not the contemporary art capitals, such as Berlin or London (or even Warsaw), but, rather, Paris of the first half of the 20th century, which has been the model of true art for traditional milieus for many decades.

What proves these professors' highs status is the fact that as experts they are jurors in art competitions, and the BWA galleries take pride in having their works in local collections, as well as they are particularly cherished as participants of pleinair workshops (their presence raises the status of a plein-air workshop, competition, or collection).

In terms of the values considered to be the most important in artistic practice, truth ranks first. The statements of the artists covered by the research suggest that it is understood as sincerity of the statements and consistency with one's own personality, which is quite significant in that paradigm - art's main task is to express the artist's internal states:

I appreciate truth. The truth which allows looking inside oneself in a reflexive way. It's not always the case that my truth is the only truth. What's important is that someone owns a mistake, [important] to looking for the truth. Admits that they miss it. I appreciate the fact that somebody doesn't pretend anything while creating. That they aren't coy. (18W50) 
Looking for truth in expressing oneself is not a fast and easy process, which is why the creative process is often described as a struggle or even a fight:

What's the most important to me is sincerity. Sincerity toward the painting, toward oneself. I also appreciate the process of struggling with creative work. (21W50)

What also appears in the statements in the context of truth is intuition and spontaneity, because the interviewed respondents believe that truth can be achieved through succumbing oneself to emotions and turning off the thought process, whereas any strategies of actions and rational decisions which are intentional and planned in advance are considered to be something insincere and are associated with negative values:

What's the most important to me now is to have some sort of truth, I don't want to invent something, some symbolisms, I'm not interested in trends, or that I will paint something in and it will be nice and striking... It was done to win acclaim, to say something, now I want it to be sincere. (08M42)

The artists from the group covered by the research distinguish themselves mainly through the form rather than the content of their works. The latter is only the pretext for the "formal search" in which, apart from truth and sincerity, esthetic values are important:

I appreciate sincerity and strictly esthetic values. I wouldn't like to come up with any message or philosophy to it, the only important thing to me is the visual aspect of the painting. (28W40)

In fact, I don't raise any topic. The topic is included in the form. (19W31)
Formal values are appreciated because of their timeless versatility; artists separate their works from the current social problems and politics, and tend to focus on existential issues, making them the main content of their message:

To me, art is a sort of escape from what's outside, it brings me closer to what's inside me. It's the essence of the entirety. I'm more interested in what's inside than in what's outside. (14M62)

[The most important thing is - A.S.D.] a worthy message which is aimed at something good, certainly quality of work and how the art work is understood... I think I want to move people and encourage them to think about the issue of sacrum and about themselves, about what we do and experience. (15M35)

One of the interviewees accurately summed up the rules which apply to the creation and presentation of art among artists from the Podkarpackie Voivodeship:

It's classical rather than avant-garde art. It features a lot of safe activity which might appeal to people. There are few actions which I appreciate in art, that is art which has something to say. Most things here are intended to be presented and not to convey a message. They are supposed to look good rather than carry a message. (04M44)

The art-related actions which are taken and promoted by artists refer to the model developed in the 19th century and at the beginning of the 20th century. Artists study at academies of fine arts or faculties of art at other universities (the former are considered to be the most prestigious) in the field of traditional media (painting, graphic art, sculpture), 
and they learn skills as a part of this process. Then, artists develop their formal skills participating in plein-air workshops, symposia and competitions. Local groups of artists keep when being in touch with similar groups in other cities and professors teaching at academies of fine arts, in the process of inviting each other to plein-air workshops and competitions.

What is problematic for them in the reception of contemporary art is not its controversial contents, but, rather, its insufficient formal and esthetic values of art works. On the one hand, artists respect the "Marcel Duchamp's gesture" and are aware of its consequences for the development of art. On the other hand, however, they still use modernist, formal criteria of assessment:

That world (I call it "false," where artists play roles from various other disciplines) is sanctioned, because such channels and such possibilities have appeared as expression by those artists through that art, which has ceased to make references to pure art, and it is based on sociology, philosophy, history, music, on some para-theatrical activities, and now we participate in a huge, mad system which has legalized fiction, inconsistency, sloppy work, ignorance... Everything heads toward a disaster, and heading toward a disaster has been, somehow, completely excluded from the genuine, sincere circulation which has shaped the human being who would like to understand the language of visual arts, to make it his/her own language and learn on its basis. (25M60)

The analysis of artists' opinions about contemporary art leads to the conclusion that they are based mainly on information about scandals which is taken out of a broader context:
In the contemporary visual arts there is a lot of trash, vile behavior, because somebody is promoted because he/she has sold an unremarkable painting for 250 thousand pounds, and there is a huge hype in media about it. There should be more humbleness and respect. A group of installation artists; they make some idiotic things, give birth to Barbie dolls, defecate from a ladder on the Mother's portrait, such actions are later filmed and shown in museums as great art. It's really bad, there are no role models.... There's a lot of dishonesty. Somehow they take money from the Ministry of Culture for something that ends up in a bin. I'm simply disgusted. (Radio program no. 15, vol. 1 of Sztuka Podkarpacia)

The artists interviewed in the research consider themselves to be the continuers of the best European artistic traditions, as well as guardians of genuine values in art:

A friend of mine said that we still paint with a brush and it's amazing. There must be something in it... that such art tends to go in the direction of intermedia, or such new art, and we are somewhere stuck in such a tradition, which is a bit connected with modernity. (Radio program no 42, vol. 3 of Sztuka Podkarpacia)

Art has boundaries when it ceases to be art. And it ceases to be art when it resorts to strange things in order to surprise us with something... I just believe that paints should be sufficient for certain things, really. (22W54)

What is also characteristic of artists who represent the model of peripheral modernity is peripherality in perceiving institutions for art circulation. It is a closed circuit within the borders created before the transformation of the political system in 1989, and as such it focuses mainly on local artistic milieus: 
The galleries which operate have easier contact with local artists and willingly exhibit their works, because they are also connected by social relationships. The galleries which are here are private, and not only private, and their exhibition activity is, to a significant extent, based on local artists, because they are in contact with them. At galleries located in Kraków, we usually can see Kraków-based artists, apart from those from other cities or countries. In our city such exhibitions also sometimes take place, but that local focus is something natural. (04M44)

The members of this environment take into account mainly big state institutions (the BWA, city galleries, and galleries owned by the ZPAP) as well as private, independent galleries, but they completely disregard centers for contemporary art or public space as a place for artistic activity. Many artists dream about an exhibition at the 'Zachęta' National Gallery of Art, but none of them strives for an exhibition at any of the CCAs.

\section{Mainstream contemporariness}

The mainstream connected with the contemporary paradigm is an art world created mainly by curators, critics, and art historians, then by artists and designers, the founders of innovative galleries, as well as the audience taking part in participatory projects. The process of the model's inception in Poland can be reconstructed if one analyzes three institutions which were crucial to its creation and operation, and which revolutionized the manner in which art and artistic institutions are perceived in Poland. According to Howard S. Becker, "an art world is born when it brings together people who never cooperated before to produce art based on and using conventions previously unknown or not exploited in that way" (2008:310).
The first institution, which began its operation at the turn of the 1980s and the 1990s - i.e. at the moment of the aforementioned political transformation - is the Ujazdowski Castle Centre for Contemporary Art, for which the contemporary paradigm becomes the basis of the program and, at the same time, a strategy to build its brand as an art institution. What was an advantage of the Centre, which started its functioning from scratch, was the absence of earlier commitments toward the artistic milieu as well as the absence of the need to break with the previous forms of operation.

The activities taken by the Centre covered the organization of exhibitions of contemporary Polish artists (the new element came in the form of employing curators and problem-focused exhibitions), the creation of a museum collection consisting of the artists' most important works, the organization of exhibitions of the most important contemporary art phenomena, and the promotion of contemporary art by means of publications (e.g. the Obieg magazine, which has been published since 2004, as well as as the Website, which has been the main platform for information and discussion about new phenomena in art).

The analysis of the contents of Obieg shows which phenomena in contemporary art were indicated as worth "mainstreaming," and which ones were disregarded (their absence in the magazine suggested they were unimportant). In the 1990s, the magazine clearly indicated the avant-garde movement in the 20th-century art as the tradition which deserves to be maintained (the theme of an avant-garde museum and the process of collecting is discussed) and continued. What was also initiated was a discussion about the need to develop a new artistic policy. Accounts from artistic events in Poland (initially, mainly in Gdańsk) and abroad (reports from New 
York, Paris, Berlin, and from international art biennales: Venice, Shanghai, Taipei) reveal which art centers are considered to be opinion-forming. The artists presented in the pages of Obieg include mainly authors of installations, objects, performances, social interventions, and video. When analyzing their biographies, one can come to the conclusion that two factors had been decisive for their choice: the avant-garde nature of the created art and the affiliation with the new, young generation of artists. The magazine published texts about artists from the older generation provided that they had gained the status of classicists of avant-garde. The articles were written matter-of-factly. The leading Polish art historians and critics contributed to the magazine (Monika Branicka, Paweł Leszkowicz, Adam Mazur, Piotr Piotrowski, Piotr Rypson, Stach Szabłowski, Magdalena Ujma, and others). In 2004, articles written by the FGF curators started to appear in it. Obieg presented contemporary events in the context of art history and the latest theories in the field of both philosophy of art and culture.

The UC CCA was involved in the presentation of critical art, performance, new media art, feminist art, socially-engaged art, and in promotion of artistic interventions or participatory projects. In all these artistic trends, traditional esthetic values have gone to the background, giving way to activities of ethical values, in which artists repeatedly cast themselves as activists or leaders of local communities. The artists also addressed the issues of exclusion, discrimination, injustice, identity-related differences, or sexuality. The most famous mainstream artists who cooperated with the UC CCA include: Katarzyna Kozyra, Zbigniew Libera, Artur Żmijewski, Joanna Rajkowska, Paweł Althamer, Elżbieta Jabłońska, Julita Wójcik, Mirosław Bałka, Zuzanna Janin, and others.
In 1995, two independent art critics - Łukasz Gorczyca and Michał Kaczyński - launched a magazine about contemporary art titled Raster, and in 2001 they officially opened a gallery under the same name. The texts published in Raster were completely different in style when compared to Obieg. The young critics put emphasis mainly on topical and up-to-date art, which draws on contemporariness and refers to young people's way of thinking and sensitivity. Initially, Raster assumed a generational character and attracted young artists, primarily painters, such as Wilhelm Sasnal, Marcin Maciejowski, or Rafał Bujnowski.

Importantly, when talking about art, they used new language, one created from ironical neologisms, which became known within the circles of the artists and institutions cooperating with Raster and Raster's Artistic Glossary (Gorczyca and Kaczyński 2009). Depending on the extent to which they were imbued with irony, the employed linguistic terms included assign positive or negative connotations to contemporary art phenomena. That attempt has created a visible boundary between what is acceptable and desirable in the new art world (i.e. in line with the contemporary paradigm), and what does not belong to it, as it is a "relic of the previous period" from the organizational and artistic point of view.

The most ironic terms refer to the framework and rules of operation of the "peripherally modern" art world and its values. The terms used by the young critics are a pun which makes references to unappetizing foodstuffs, popular culture, rural areas, or natural suspensions and secretions. In such a way, they construct the mainstream which establishes new trends with the vision of "folksy" peripheries, in which time had stopped before the political 
transformation. The terms which appear here include, inter alia:

- "Arte polo" - i.e. paintings by masters such as Zdzisław Beksiński, Jerzy Duda-Gracz, Franciszek Starowieyski, here compared to popular dance music (Gorczyca and Kaczyński 2009:22-24);

- "Błoto" ["Mud"] - a painting whose typical feature is the technique of "the brush which gets bogged," i.e. "poking in paint as if it was mud" (Gorczyca and Kaczyński 2009:27);

- "Gluciarz" ["A snoter"] - a Polish abstractionist sculptor ("bronze snot" means an abstract sculpture made of bronze) (Gorczyca and Kaczyński 2009:34);

- "Stolec" ["Stool"] - a figural sculpture made of bronze (Gorczyca and Kaczyński 2009:50);

- "Buła" ["A tasteless bun"] - the Artistic Exhibitions Bureaux, the "synonym of artistic junk," according to the critics (Gorczyca and Kaczyński 2009:28);

- "Zakalce" - ["Sad layers"] - exhibitions (salons, reviews, triennials) organized by "tasteless buns" (Gorczyca and Kaczyński 2009:29);

- "Lack of Content Syndrome" - "the most common disease among Polish painters" who believe that art is a separate, autonomous world, which is why the art work's form is its content (Gorczyca and Kaczyński 2009:52).

The concepts bearing positive associations, related to the phenomena which critics believe to be worth promoting, include:
- "Ambit" - i.e. the most ambitious type of a collective exhibition, the so-called "problem exhibition," based on the curator's idea and selection (Gorczyca and Kaczyński 2009:21);

- "As" ["Ace"] - a pun, as the ace is the highest card in the deck and, in Polish, it is also the abbreviation for the "Network Artist" (Gorczyca and Kaczyński 2009:25);

- "Kowalnia" - the sculpture studio run by Professor G. Kowalski, which educates students in the contemporary paradigm (Gorczyca and Kaczyński 2009:38) (a pun associated with "a forge of talent");

- "Foxes" - i.e. the curators of the FGF (a pun using the similarity of the word "fox" and the name of the gallery, which connotes the curators' cunning) (Gorczyca and Kaczyński 2009:39);

- "Sieć" ["Network"] - a system upon which the operation of contemporary art in Poland is based, i.e. a network of institutions throughout the country which cooperate with the "Network Artists" and top curators, among which the central position is held by the UC CCA.

What was the most important for the new art world which was taking shape at that time was separation, by the Raster critics, of a new network operating in Poland - an "integrated circuit" of institutions which connected by a shared vision of art would cooperate with one another, implementing similar programmes with participation of the group of artists and curators "consecrated" by them. In such a way, the polarisation has taken place as part of which peripheries, that are faithful to modern tra- 
ditions and distance themselves from the "circuit," oppose the "network of institutions," which follows the contemporary paradigm and has gradually secured the mainstream position.

The actions taken by the curators of the young Foksal Gallery Foundation, which focused on the introduction of Polish artists to the global art circulation, have deepened that polarization even further. The Foksal Gallery Foundation was created at the avant-garde Foksal Gallery in Warsaw in 1997, and in 2001, its creators - i.e. Joanna Mytkowska, Andrzej Przywara, and Adam Szymczyk - separated the Foundation from the Foksal Gallery, changing it into an independent, commercial art gallery. Since the very beginning, the Foundation's founders have built their reputation by means of acting as experts in the field of the latest trends for visual arts in the world. The works created by the artists whom they subsequently represented as an independent gallery followed the above-mentioned trends. What confirmed the competence of the young curators was a number of successes at international art fairs (e.g. the Art Basel in Basel and the Frieze Art Fair in London), as well as positions held at prestigious art institutions (in 2003, A. Szymczyk became the director of the Kunsthalle Basel, whereas in 2007, J. Mytkowska became the director of the Museum of Modern Art in Warsaw).

The FGF started to collaborate with artists from different generations; the criterion was whether their work fitted in with the global trends in visual arts. The Foundation ensured the effective promotion of the represented artists (such as Paweł Althamer, Robert Kuśmirowski, Wilhelm Sasnal, Monika Sosnowska, Piotr Uklański, Artur Żmijewski, and others), who quickly entered the world of art circulation.
Since the very beginning, the FGF's curators have been active in the international circulation, eliminating the differences between the Polish and international contemporary arts, which is visible in the manner in which texts about the organized exhibitions and the artists represented by the Foundation are constructed. The texts feature references to global trends in visual arts, the leading theories, events such as the biggest global art exhibitions and biennales, as well as concepts put forward by world-famous curators. From this perspective, local milieus from outside of the "network" become doubly peripheral, and their activities are located completely outside the major canons of art.

\section{Conclusion}

The process of the creation of a new art world in Poland begins with the change of the political system and the opening of the borders, and the three above-mentioned institutions determine the three stages of that process. The following elements are created at the first stage: a new canon of contemporary art, innovative strategies of its dissemination, new concepts to describe it, new intermediaries (curators), and, most importantly, a "network" of institutions which operate in accordance with the new rules. The second stage involves separation by means of clearly indicated differences and, owing to it, drawing the line between the two art worlds. The third stage is about the inclusion of the new art world into the global network of contemporary art.

From among the texts on art written at the three above-mentioned stages, one can identify the main categories, on the basis of which the distinction is made. First, these are categories of novelty, youth, avant-gardism, and contemporariness. Then, the term "topicality" is added (a selection of art which 
is a direct dialog with "here and now"). The third stage involves the "dynamism of change" (giving an account of the phenomenon of "fluidity" in the global art world). Curators are the directors of the whole process, and it is them who, through institutions which they represent, are authorized to create new definitions of art and the artist.

In the "mainstream contemporariness" model, art is a space for discussion about the contemporary times which is attended, apart from the artist, by numerous "intermediaries," and what is accepted is even the de-materialization of the art work itself, or a resignation from its authorship in order to highlight relations in the art world. The artist resembles an intellectual who is often committed to political and social affairs. The members of the new art world compete on a free global art market, subjecting themselves to its processes and requirements.

The second model, i.e. the model of "peripheral modernity," which exists through the shape which has been unchanged for decades, protects its identity by highlighting the tradition's continuity (Academy, masters, the improvement of techniques). Professors and masters create valid definitions of art and the artist in it. In that world, the assessment of art is made on the basis of esthetic categories and values such as truth and sincerity. The relevance of the romantic myth about disinterested art leads to the separation of creative activity from gainful activity as well as mistrust toward the art market. Above all,

\section{References}

Banasiak, Jakub, ed. 2009. Raster. Macie swoich krytyków. Antologia tekstów. Warsaw: 40000 Malarzy. this model highlights the autonomy of the art work and the artist.

Even if the two art worlds do not seem to be completely separate for researchers, they are such for the participants of these worlds. Art worlds are social worlds constructed by their participants, and, in this particular case, the participants construct them as two opposite communities of meanings.

Statements by Piotr Bernatowicz (the director of the UC CCA since 2020), seem to confirm the profound polarization of the two art worlds in Poland. According to him, "In every large gallery we have the same thing - socially engaged art, feminist art, art defending minorities and criticizing the Church... art is more diverse, but institutions do not show it" (Bernatowicz 2019). His new idea for the UC CCA is to present conservative artists and to "make the dominant art less dominant" (Bernatowicz 2019). He is criticized for his beliefs, but in his opinion, "the reason for these attacks is that [his - A.S.D.] conservative views break out of the monolith of directors of major art institutions and curators" (Bernatowicz 2019). As he explains, "[his - A.S.D.] views have indeed evolved toward conservatism, but the artistic mainstream has also radicalized. This mainstream art world has begun to drift strongly toward the left, neo-Marxism" (Bernatowicz 2019). Bernatowicz notices a polarization among Polish artists, curators, and institutions, and explains his own actions as resulting from the need to weaken the mainstream and strengthen that which has been marginalized.

Becker, Howard. 2008. Art Worlds. Berkeley: University of California Press. 
Bernatowicz, Piotr. 2019. Sztuka współczesna nie musi być wcale lewicowa. Retrieved February 20, 2021 (https://dorzeczy. $\mathrm{pl} / \mathrm{kraj} / 118987 /$ sztuka-wspolczesna-nie-musi-byc-wcale-lewicowa.html).

Charmaz, Kathy. 2006. Constructing Grounded Theory. A Practical Guide Through Qualitative Analysis. London, Thousand Oaks, New Delhi: SAGE Publications.

Cohen, Anthony. 2001. Symbolic Construction of Community Key Ideas. London, New York: Department of Social Anthropology University of Manchester.

Dziamski, Grzegorz. 2010. Przełom konceptualny. Poznan: Wydawnictwo Naukowe UAM.

Glaser, Barney G. and Anselm L. Strauss. 2009. Odkrywanie teorii ugruntowanej. Cracow: Zakład Wydawniczy Nomos.

Gorczyca, Łukasz and Michał Kaczyński. 2009. "Słowniczek artystyczny Rastra." Pp. 21-55 in Raster. Macie swoich krytyków. Antologia tekstów, edited by J. Banasiak. Warsaw: 40000 Malarzy.
Heinich, Nathalie. 2014. Le paradigme de l'art contemporain. Structure d'une révolution artistique. Paris: Éditions Gallimard.

Heinich, Nathalie. 2019. Sztuka jako wyzwanie dla socjologii. Gdansk: Słowo/ Obraz/ Terytoria.

Konecki, Krzysztof T. 2000. Studia z metodologii badań jakościowych. Teoria ugruntowana. Warsaw: Wydawnictwo Naukowe PWN.

Luhmann, Niklas. 2016. Pisma o literaturze i sztuce. Warsaw: Wydawnictwo Naukowe SCHOLAR.

Piotrowski, Piotr. 1999. Znaczenia modernizmu. Poznan: Rebis.

Rabizo-Birek, Magdalena, ed. 2011-2013. Sztuka Podkarpacia, vol. 1, vol. 2, vol. 3. Rzeszow: Podkarpackie Towarzystwo Zachęty Sztuk Pięknych.

Stake, Robert. 1994. “Case Studies.” Pp. 236-247 in Handbook of Qualitative Research, edited by N. Denzin and Y. Lincoln. Thousand Oaks, London, New Delhi: Sage.

\title{
Citation
}

Sulikowska-Dejena, Agata. 2021. “Two Paradigms - Two Art Worlds: On Constructing the Difference as a Strategy for Validating the Concept of the Artist and Art." Przeglad Socjologii Jakościowej 17(3):112-125. Retrieved Month, Year (www.przegladsocjologiijakosciowej.org). DOI: https://doi.org/10.18778/1733-8069.17.3.06

\section{Dwa paradygmaty - dwa światy sztuki. O konstruowaniu różnicy jako strategii uprawomocnienia koncepcji artysty i sztuki}

\begin{abstract}
Abstrakt: Przedmiotem artykułu są dwa światy artystyczne w obszarze sztuk wizualnych, które obecnie działają obok siebie w Polsce. Światy te funkcjonują w ramach dwóch różnych paradygmatów sztuki, przez co obowiązują w nich dwie różne definicje sztuki i artysty, a co za tym idzie, również różne modele działań. W przypadku obydwu wspólnot istotny jest proces konstruowania różnicy i wyodrębnienia własnej wspólnoty znaczeń, jako strategii uprawomocnienia własnej koncepcji sztuki i artysty oraz własnej, zajmowanej w świecie artystycznym (ang. art world) pozycji. Celem artykułu jest pokazanie, jak przebiega proces konstruowania wewnętrznych granic w polskim art world, a także jego podział na dwa odrębne światy oraz to, jakich środków użyto w owym procesie i jakie konsekwencje niesie przynależność do odrębnych światów artystycznych dla ich uczestników.
\end{abstract}

Słowa kluczowe: paradygmat nowoczesny, paradygmat współczesny, konstruowanie różnicy, świat sztuki, sztuki wizualne 